УДК 947. 04 «1896-1944»

DOI 10.24919/2519-058X.5.116975

Оксана МЕДВІДЬ,

orcid.org/0000-0002-8777-9760

кандидат історичних наук, доцент кафедри історії України

Дрогобицького державного педагогічного університету імені Івана Франка

(Україна, Дрогобич) oksana-medvid@ukr.net

\title{
ПОСОЛЬСЬКІ ВИСТУПИ ДМИТРА ПАЛІЕВА У ПАРЛАМЕНТІ ДРУГОЇ РЕЧІ ПОСПОЛИТОЇ
}

\begin{abstract}
У статті проаналізовано посольські виступи Дмитра Палієва у парламенті міжвоєнної Польщі. Стверджено, щзо сеймові виступи Д. Палієва були завжди гострополітичними, бо підіймали важливі проблеми національно-культурного життя західних украӥнців. Показано, щуо він критикував освітню та релігійну політику польського уряду, протестував проти руйнування православних иеерков на Холмщині $i$ Волині.

Ключові слова: Дмитро Палїв, парламент Другої Речі Посполитої, посольські виступи, національно-визвольний рух.
\end{abstract}

Лim. 15.

Oksana MEDVID'

Ph D (History), Associate Professor of Ukraine's History Department, Drohobych Ivan Franko State Pedagogical University

(Ukraine,Drohobych) oksana-medvid@ukr.net

\section{DMYTRO PALIYIV'S AMBASSADORIAL SPEECHES IN THE PARLIAMENT OF POLAND'S SECOND RZECZ POSPOLITA}

The article deals with Dmytro Paliyiv's critical speeches in Polish parliament in 1928 - 1930. It shows how he argued with Polish politicians and historians and makes an accent on the fact that the Ukrainians had to fight for the restoration of the Ukrainian state on the lands that transferred to Poland. In his speeches D. Paliyiv constantly pointed out the great state-formation potential of the Ukrainians who created the powerful Kyivan Russ at the turn of the I and II millennia and whose traditions were taken over by the Galician-Volhynian state. It is stated in the article that D. Paliyiv's parliamentary speeches were always politically acute as they concerned the important issues of the national and cultural life of western Ukrainians. He is also known to criticize the educational and religious policy of the Polish government, protesting against the destruction of the Orthodox church in Kholm land and Volhynia.

He angrily condemned chauvinistic stamps on the Ukrainians and the Ukrainian lands, like "Malopolska», "Cresy», etc. He substantiated the appearance of such historical ethnonyms as "Rus'», "Ukraine», "Ukrainians», and underlined the necessity in development the Ukrainian national schools and cultural institutions like «Prosvita» and «Ridna Shkola», cooperative associations like «Maslosoyuz» and «Silskyi Hospodar», not forgetting about the economical self-sufficiency of his Ukrainian countrymen.

Ambassador D. Paliyiv repeatedly accommodated his eye upon inviolability in the different places of Pokutia. He frequently incited the Polish government, calling for the removal of Ukrainian lands from Poland and creation of independent Ukrainian state.

The article states that Paliyiv was not only a true representative of his Kolomyia district, but one such of the whole Galicia for whose freedom he bravely fought in 1914 - 1920. Dmytro Paliyiv was a typical representative of Ukrainian national liberation movement of the first half of the XX century. His right-wing radical views were not always recognized by the society, but they always intensified social actions against invaders.

Key words: Dmytro Paliyiv, the Parliament of Second Polish Republic, deputy speeches, national liberation movement.

Ref. 15 . 
Оксана МЕДВИДЬ,

кандидат исторических наук, доиент кафедры истории Украинь Дрогобычского государственного педагогического университета имени Ивана Франко (Украина, Дрогобыч) oksana-medvid@ukr.net

\title{
ПОСОЛЬСКИЕ ВЫСТУПЛЕНИЯ ДМИТРИЯ ПАЛИЕВА В ПАРЛАМЕНТЕ ВТОРОЙ РЕЧИ ПОСПОЛИТОЙ
}

\begin{abstract}
В статье проанализированы посольские выступления Дмитрия Палиева в парламенте межвоенной Польши. Утверждено, что сеймовые выступления Д. Палиева были всегда острополитическими, поднимавшими важные проблемы национально-культурной жизни западных украинцев. Показано, что он критиковал образовательную и религиозную политику польского правительства, протестовал против разрушения православных иеерквей на Холмщине и Вольни.
\end{abstract}

Ключевые слова: Дмитрий Палиев, парламент Второй Речи Посполитой, посольские выступления, национально-освободительное движение.

Лит. 15.

Постановка проблеми. Після поразки у війні 1918 - 1919 рр., всупереч своїй волі й внаслідок воєнних дій, західні українці опинилися у складі Другої Речі Посполитої, яка в їхніх очах постала як окупаційна влада. Неприязне ставлення краян до неї підкріплювалося дискримінаційною щодо українців державною національною політикою. Перед західноукраїнськими політиками постала непроста дилема: або визнати нову польську владу і будувати своє національно-культурне життя в межах чужої їм держави, або ж продовжувати жертовну і нерівну боротьбу в нових політичних умовах. Частина політиків пішли в підпілля для організації подальшої збройної боротьби, інші заявили про свою лояльність до відродженої Польської держави і намагалися домогтися від уряду культурно-освітніх і господарських поступок для українців. I чи не найбільша частина партій, залишаючись в опозиції до Варшави, перейшла до легальної роботи і зосередилася на парламентській роботі. Дмитро Паліїв обрав перший, найнебезпечніший, шлях боротьби й невдовзі став одним із чільних діячів праворадикального табору національного-визвольного руху, фундатором УВО, УНДО, Фронту національної єдності.

Аналіз останніх досліджень і публікацій засвідчує, що діяльність Д. Палієва в парламенті Другої Речі Посполитої ще не знайшла об'єктивного висвітлення в історичній літературі. У 40 - 80-х рр. в діаспорі з'являється низка праць про військово-політичну діяльність Дмитра Палієва. Зокрема, С. Волинець у нарисі «Предвісники і творці листопадового зриву. Західноукраїнські політичні діячі» викладає найважливіші віхи біографії Д. Палієва [4]. Окремі маловідомі сюжети його політичної діяльності знаходимо у працях, П. Мірчука «Нарис історії ОУН. 1929 1939 роки» [7], I. Кедрина «Життя. Події. Люди: Спомини та коментарі» [6], М. Гуцуляка «Перший Листопад 1918 року на Західних землях України. Зі спогадами та життєписами членів Комітету виконавців Листопадового чину» [5]. Зі спеціальних робіт, присвячених політичній діяльності Д. Палієва у 30-і рр., насамперед виділимо розвідки М. Швагуляка, в яких аналізуються передумови розколу праворадикального табору і створення відкрито опозиційного до Польської держави Фронту національної єдності $[14 ; 15]$. Однак у більшості з цих робіт не проаналізовано його посольські виступи у сеймі міжвоєнної Польщі.

Мета статті - на основі нових історичних фактів висвітлити діяльність Дмитра Паліїва у парламенті Другої Речі Посполитої, показати його роль у боротьбі галицьких українців за національно-державну незалежність.

Виклад основного матеріалу. Після поразки визвольних змагань 1914 - 1920 рр. Дмитро Паліїв повернувся до Галичини. У другій половині вересня 1921 р. його обрали до Начальної Команди Української військової організації. Восени 1921 р. відновило свою діяльність спортивне товариство «Україна». Його головою обрали Д. Паліїва. 3 квітня 1923 р. він працював співредактором часопису «Заграва», а восени того ж року заснував ще один часопис національно-патріотичного спрямування - газету «Новий час». Це видання мало сприяти організаційній праці серед широких верств як одній із найважливіших передумов майбутнього державотворення. 
Проте вже у 1925 р. відбулися значні зміни в українському політичному житті краю. Уперше після майже дворічного періоду поділів і гострих суперечок у політичному середовищі були зроблені рішучі кроки до консолідації. Ї̈ї початком стало ідейне та організаційне зближення різних політичних груп на базі дотеперішньої Української народно-трудової партії. На початку 1925 р. народилася ідея про об’єднання Незалежної групи (до неї належали члени УНТП, які виступали проти різкої зміни політики партіі) з колом «Заграви». Ініціатива в цій справі належала Д. Палієву. За якийсь час до них приєдналася група «Діла» та українські сеймові посли від Волині. На спільному конгресі УНТП, УПНР, Національної групи Української парламентної репрезентації (УПР) і групи «Діла», що проходив 11 липня 1925 р. у Львові, було ухвалено об’єднати всі ці сили в одну партію під назвою «Українське національно-демократичне об’єднання». На з’їзді обрано Центральний комітет УНДО, до якого увійшов і Д. Паліїв. Нова партія прийняла основні програмні положення платформи УНТП $[8,2]$.

У 1928 р. УНДО вперше взяло участь у виборах до вищих законодавчих органів Польщі. Гостра критика національної політики польської влади на українських землях забезпечила УНДО значну підтримку українського населення: 23 представники партії здобули посольські мандати, 9 стали сенаторами. Послом до сейму в Коломийській окрузі був обраний Дмитро Паліїв $[11,5]$.

Парламентська тактика УНДО продовжувала передвиборчу лінію партії, до чого значною мірою спричинилася група Д. Палієва. Український клуб виступав у сеймі з гнучкими політичними заявами, які поєднували тези про незмінність українських державницьких цілей із критичними заувагами про становище західноукраїнських земель під Польщею. На засіданні 29 березня 1928 р. голова українського клубу Д. Левицький оголосив декларацію, в якій підкреслювалося: український народ не визнає жодних трактатів і міжнародних актів, за якими передали західні українські землі до Польщі, і тому прагнутиме відтворити на них незалежну Українську державу $[11,5]$.

У сеймовій промові під час генеральної бюджетної дискусії 31 січня 1929 р. Д. Паліїв полемізував із польськими істориками та політиками, які доводили «історичні права» Польщі на Галичину і трактували український самостійницький рух як витвір зовнішніх чинників. Заперечивши твердження про те, що українці вороже ставляться до поляків, він заявив: «Ми не є ворогами польської держави, але тільки ворогами тієї помилки історії, якою є Польща в нинішніх границях» $[13,2]$.

Сеймові виступи Д. Паліїва були завжди гострополітичними, бо підіймали важливі проблеми національно-культурного життя західних українців. Зокрема, у виступі 15 червня 1928 р. він взяв участь у дискусії щодо заборонених термінів «Західна Україна» і «українець»: «Посол д-р Західний вжив терміну «Західна Україна» для окреслення українських земель, які тепер належать до Польщі. Потверджую і маю честь потвердити в імені Українського Клубу, що цього і тільки цього терміну ми вживаємо, і цей термін не означає Наддніпрянську Україну, яка тепер належить до Союзу Соціалістичних Республік, а саме Західну Україну, це значить ті українські землі, які Польща прилучила до себе, незважаючи на їх волю і волю всього українського народу. І ми ніколи не дамо вирвати цього означення, і та цілість завжди становитиме для нас Західну Україну, яка має стремління сполучатися із Східною Україною, щоб обстоювати з нею одну цілість» $[1,1]$.

31 січня він знову критикує офіційну Варшаву за обмеження національно-культурних прав українців. Особливій критиці піддано політику уряду П. Грабського, а згодом і правління Ю. Пілсудського: «Але сьогодні Польща є для українців тим, чим була для Польщі Росія, Австрія і Німеччина. Ви, панове, повернулися до перестарілої теорії, що зазнала краху: нема українського народу. Кажете: є племена, етнічні групи, є гуцули, волиняки, поляни і т.д., майже, що повіт, то інший народ. Пан віце-воєвода в Тернополі сказав на зборах війтів, що України не було, нема i не буде, що ви собі вибийте з голови ту Україну, бо немає українського народу. Але без сумніву, п. Стронський посувається задалеко, коли твердить, що ще в XIII і ХІУ століттях Східна Галичина й інші українські землі були територією, на якій жили два народи: польський і український, а український вже тоді становив меншість. Для потвердження (аргументаціі) цього твердження напевно не вистарчить навіть доказів вашої Академії Наук в Кракові» [1, 3].

У цьому ж виступі він також доводить праетнічність Надсяння: «Пан Стронський твердить також, що Східна Галичина приналежна до Польщі вже 6 століть. В наші часи доказувати свої 
права такими аргументами дуже ризиковано. Ніхто і ніщо не заперечить, що ми втратили нашу державність в XIV ст., але ми посідали ії впродовж століть там, де тепер є наша етнографічна територія... Ми втратили тоді ті терени в боротьбі. Але все ж проблема самостійної України існує, якщо не як актуальне питання міжнародної політики, то як справа, яка не перестає займати уми публічної опінії» $[8,2]$. Далі Д. Паліїв критикує національну політику Речі Посполитої. Закінчується промова гостро патріотичними аргументами: «Історія повчає нас, що немає такої сили, яка могла б здавити остаточно народ, що має незломну волю до власного буття» $[1,5]$.

Того ж дня Паліїв ще раз виступив із критикою освітньої та релігійної політики Бельведера: «Чи толерантністю $є$ закриття двох з половиною тисяч українських шкіл і перетворення їх на польські чи утраквістичні? Чи толерантно це, що на Волині, де згідно з Вашою статистикою, проживає 1060000 українців і 160000 поляків, в польських школах навчалось 75000 дітей, в утраквістичних 40 000, а в українських 551 дитина? Чи толерантність можна вважати те, що на Поліссі, де проживає 650000 українців, а 69000 поляків, згідно з Вашою статистикою, в польських школах вчиться 82000 дітей, в утраквістичних 124 дитини, а в українських 548 дітей? Чи толерантністю $є$ нищення української преси таким чином, що напр. У львівському тижневику «Свобода» конфіскуються ті статті, які ще тиждень перед тим не були сконфісковані?» $[1,5]$.

Далі він гостро протестував проти руйнування православних церков на Холмщині та Волині: «Чи можна назвати толерантність закриття 400 чи 500 церков на Волині і Холмщині? Чи толерантність $€$ карання людей гривною за спів народного гімну «Не пора»? Чи толерантністю $€$ допущення владою безкарного нищення впродовж трьох днів українського майна в пам'ятних днях листопада? Чи є врешті толерантністю такий дрібний, але характерний випадок - покарання гривною в сумі 10 золотих чоловіка, який зібрав на весіллі на українських інвалідів суму 8 - 10 золотих; це на тих українських інвалідів, яким ви відмовляєте інвалідських виплат. Толерантністю називаєте хіба те, що не женете нас на Сибір, але це не Ваша заслуга. Сибіру не маєте. Тільки в'язниці всі повні політичних в'язнів. Пан предсідник Домбський говорив сьогодні про царську Росію. Ви, як політичні в’язні, мали там статус політичних в'язнів, натомість в Польщі трактують політичних в'язнів як звичайних злочинців, тому що, згідно з законом, між ними немає ніякої різниці» $[1,9]$.

4 лютого 1930 р. Д.Паліїв взяв участь у сеймовому обговоренні проблеми еміграції і справ інвалідів. Зокрема він підкреслив необхідність ліквідації соціально-економічного підгрунтя виїзду знедолених за океан: «Те, що діється в еміграційній політиці, це відверта торгівля живим товаром, підтримувана державою. Я поставив на Бюджетовій Комісії внесок, щоб вибрати спеціальну комісію, яка б провірила всі справи, зв'язані з еміграцією, бо там дійсно відбуваються страшні речі. Пан референт навіть не згадав у своїм справозданні про еміграцію до Перу. Говорено про Анголу, Бразилію, Канаду, Палестину, США, але про те, що найважніше, про еміграцію до Перу, що рекрутується передовсім з волиняків, в якій, по суті, відбувається торгівля живим товаром, пан референт, на жаль, не згадав. Так, бо там більше як два роки не витримає наша людина, а держава це толерує. Тому Український Клуб знову рекомендує вибрати спеціальну комісію, яка провірила б справу еміграції і зв'язану з тим справу корабельних ліній, упревілейовання їх і т.д.» $[2,2]$.

У справі допомоги інвалідам він зауважив: «Друга справа, це справа інвалідів. Мушу ствердити, що з Міністерства Суспільної Опіки по сьогодні ні гроша не видано на українські цілі. На жаль, ці внески зустрілися з єдино думною відмовою. Голосували за ними лише народні меншини, а навіть лівоцентровий, навіть клуб п. голови Чапинського голосував проти. Щоб сиротам допомогти, на те $\epsilon$ закон, і не лише закон, але й обов'язок Міністерства. Тільки таким способом можна розв'язати це» $[9,2]$.

Ще гострішим був його виступ 14 березня 1930 р., в якому він розкритикував політику польської колонізації західноукраїнського терену: «Внесені проекти нових законів щодо осадництва $€$ найкращим доказом того. Історія нічого не навчила. Певні своєї сили, Панове, йдете шляхом, що нічого доброго не ворожить. Помайові уряди - це уряди декламаторів. Не можна творити громадян різних категорій - декларують вони, і тут же в комісіях і всюди інше панове з санації, а водночас санаційні уряди вносять закони про осадництво, ліквідують українські школи, руй- 
нують самоуправу й ведуть відносно українських земель політику колоніальну. Говориться про вщеплення в українське населення польського патріотизму, забуваючи про фізичний закон, що два предмети не можуть поміститися на одному місці» [6, 325].

Він осудив також фізичні розправи над українськими патріотами, зокрема у Рівному (березень, 1930): «Окрім посла Серветника, заарештовано ще 172 особи, з них більше як 30 побито; між іншим заарештовано 5 учнів. Ви кажете, панове, що це неправда, говорите завжди те саме. Дійсно, як ви кажете, що не можна узагальнювати поодинокі факти. Коли ж говоримо загально, тол ви кажете: дайте факти. Це характерно для польської політики Міністерства Внутрішніх Справ у відношенні до українського народу».

У своїх виступах Д. Паліїв постійно відзначав великі державотворчі потенції українців, які на рубежі I - II тисячоліть створили могутню Київську Русь, традиції якої перейняла Галицько-Волинська держава. Тому він гнівно осуджував шовіністичні штампи щодо українців та українських земель на зразок «Малопольща», «креси» і т.д. Він обгрунтовував давні історичні етноніми «Русь», «Україна», «українці». Уважав за потрібне розвивати національне шкільництво, національно-культурні установи - «Просвіту». «Рідну школу». При цьому не забувати про економічну самодостатність краян і розвивати українські кооперації в особі «Маслосоюзу» та «Сільського господаря» $[10,3]$. Посол Паліїв почував себе дійсним представником не лише своєї округи Коломийщини, але й всієї Галичини, за волю якої у 1914 - 1920 рр. боровся зі зброєю в руках.

Слід зауважити, що посол Д. Паліїв не раз використовував недоторканість для влаштування посольських віч у різних місцевостях Покуття. Не раз підбурював проти польського уряду, закликав до від’єднання українських земель від Польщі й творення власної держави $[7,436]$.

Масова репресивна операція уряду Польщі проти українського населення Галичини восени 1930 р. стала могутнім каталізатором суспільного руху. В ніч 99 на 10 вересня ц.р.були проведені арешти групи визначних українських діячів. У числі перших був ув'язнений Д. Паліїв. Таємний меморандум Міністерства юстиції прокуророві при апеляційному суді у Львові від 5 листопада 1928 р. вказував на зростання у краї «національних антагонізмів» і «антидержавних тенденцій». На підтвердження наводилися фрагменти з промов Д. Палієва на вічах у різних місцевостях, де він наголошував на рішучих намірах боротися за свою незалежну соборну державу. Міністерство стверджувало, що така діяльність послів «становить серйозну небезпеку і вимагає здійснення якнайефективніших кроків для протидії їй» $[12,11]$.

Міністерство внутрішніх справ склало список депутатів-опозиціонерів та сформулювало звинувачення проти кожного з них. У цьому списку Ю. Пілсудський власноручно позначив тих, хто мав бути заарештований і замкнений до військової в'язниці у Бресті. Звинувачення базувалися на публічній діяльності ув’язнених. Д. Паліїву, зокрема, ставили у провину численні антидержавні промови у 1928 р. У листопаді 1930 р. Паліїв разом з іншими чотирма послами був перевезений із Бреста до карно-слідчої тюрми у Львові. Тут над кожним із них відбувся окремий судовий процес.

Суд над Д. Палісвим, що проходив у червні 1932 р., вирізнявся 3-поміж інших з огляду на тягар оскаржень та особливу поведінку підсудного, що був сповнений великої гідності та почуття відповідальності за справу, яку представляв. Свої зізнання у суді Д. Паліїв використав для викладення власного політичного кредо. Відповідаючи на звинувачення в державній зраді, він заявив: «По своїм поглядам я націоналіст. Стою на становищі, що кожна нація має право сама собою порядкувати й у своїй власній державі доходити найвищих щаблів збірного розвитку» $[11,5]$.

Висновки. Дмитро Паліїв був типовим представником українського національно-визвольного руху першої половини XX ст. Його праворадикальні погляди не завжди сприймало суспільство, але вони значно активізували суспільні дії проти окупантів. У своїх виступах Д. Паліїв постійно відзначав великі державотворчі потенції українців, які на рубежі I - II тисячоліть створили могутню Київську Русь, традиції якої перейняла Галицько-Волинська держава. Тому він гнівно осуджував шовіністичні штампи щодо українців та українських земель. Посол Паліїв почував себе дійсним представником не лише своєї округи Коломийщини, але й всієї Галичини, за волю якої у 1914 - 1920 рр. боровся зі зброєю в руках. 


\section{СПИСОК ВИКОРИСТАНИХ ДЖЕРЕЛ І ЛІТЕРАТУРИ}

1. Архів Інституту українознавства ім. І. Крип'якевича НАН України. Посольські виступи Д. Паліїва. 15 червня 1928 p.

2. Архів Інституту українознавства ім. І. Крип’якевича НАН України. Посольські виступи Д. Палієва. 4 лютого $1930 \mathrm{p}$.

3. Верига В. Дмитро Паліїв - воїн і патріот $(1896$ - 1944) / В. Верига // Вісті Комбатанта. Торонто - НьюЙорк: Червона Калина. - 1968. - Ч. 5-6. - С. 35-46.

4. Волинець С. Предвісники і творці листопадового зриву. Західноукраїнські громадські і політичні діячі / Степан Волинець. - Вінніпег: Тризуб, 1965. - 324 с.

5. Гуцуляк М. Перший листопад 1918 року на Західних землях України зі спогадами і життєписами членів Комітету Виконавців Листопадового Чину / Михайло Гуцуляк. - К.: Либідь, 1993. - 403 с.

6. Кедрин І. Життя - події - люди. Спомини і коментарі / Іван Кедрин - Нью-Йорк: Червона Калина, 1976. $-721 \mathrm{c}$.

7. Мірчук П. Нарис історії ОУН. 1929 - 1939 роки / П. Мірчук. - К.: Українська видавнича спілка, 2007. $-1008 \mathrm{c}$.

8. Паліїв Д. Битись чи миритись? / Д. Паліїв // Діло. - 1928. - 15 квітня. - С. 2.

9. Паліїв Д. Після першої сесії польського сойму / Д. Паліїв // Новий час. - 1928. - Ч. 78 (530). 29 червня. - С. 2.

10. Паліїв Д. Відповіді на мовчанку / Д. Паліїв // Новий час. - 1929. - Ч. 67. - С. 2-3.

11. Ц ЦДІА у Львові. - Ф. 205. - Оп. 1. - Спр. 840.

12. ЦДІА у Львові. - Ф. 205. - Оп. 1. - Спр. 853.

13. ЦДІА у Львові. - Ф. 344. - Оп. 1. - Спр. 517.

14. Швагуляк М. Національно-політична діяльність Дмитра Паліїва у міжвоєнний період. / М. Швагуляк // Україна: культурна спадщина, національна свідомість, державність. Збірник наукових праць. Випуск 7. - Львів: Інститут Українознавства ім. І. Крип’якевича НАН України, 2000. - С. 404-428.

15. Швагуляк М. Польська репресивна акція у Галичині 1930 р. і українська суспільність / М. Швагуляк. - Львів: Інститут українознавства ім. І. Крип'якевича НАН України, 1993. - 52 с.

\section{REFERENCES}

1. Arkhiv Instytutu ukrainoznavstva im. I. Krypiakevycha NAN Ukrainy. Posolski vystupy D. Paliiva. 15 chervnia $1928 \mathrm{r}$.

2. Arkhiv Instytutu ukrainoznavstva im. I. Krypiakevycha NAN Ukrainy. Posolski vystupy D. Paliieva. - 4 liutoho $1930 \mathrm{r}$.

3. Veryha V. Dmytro Paliiv - voin i patriot $(1896$ - 1944) / V. Veryha // Visti Kombatanta. Toronto - Niu-York: Chervona Kalyna. - 1968. - Ch. 5-6. - S. 35-46.

4. Volynets S. Predvisnyky i tvortsi lystopadovoho zryvu. Zakhidnoukrainski hromadski i politychni diiachi / Stepan Volynets. - Vinnipeh: Tryzub, 1965. - 324 s.

5. Hutsuliak M. Pershyi lystopad 1918 roku na Zakhidnykh zemliakh Ukrainy zi spohadamy i zhyttiepysamy chleniv Komitetu Vykonavtsiv Lystopadovoho Chynu / Mykhailo Hutsuliak. - K.: Lybid, 1993. - 403 s.

6. Kedryn I. Zhyttia - podii - liudy. Spomyny i komentari / Ivan Kedryn - Niu-York: Chervona Kalyna, 1976. $-721 \mathrm{~s}$.

7. Mirchuk P. Narys istorii OUN. 1929 - 1939 roky / P. Mirchuk. - K.: Ukrainska vydavnycha spilka, 2007. $-1008 \mathrm{~s}$.

8. Paliiv D. Bytys chy myrytys? / D. Paliiv // Dilo. - 1928. -15 kvitnia. - S. 2.

9. Paliiv D. Pislia pershoi sesii polskoho soimu/ D. Paliiv // Novyi chas. - 1928. - Ch. 78 (530). -29 chervnia.

- S. 2.

10. Paliiv D. Vidpovidi na movchanku / D. Paliiv // Novyi chas. - 1929. - Ch. 67. - S. 2-3.

11. TsDIA u Lvovi. - F. 205. - Op. 1. - Spr. 840.

12. TsDIA u Lvovi. - F. 205. - Op. 1. - Spr. 853.

13. TsDIA u Lvovi. - F. 344. - Op. 1. - Spr. 517.

14. Shvahuliak M. Natsionalno-politychna diialnist Dmytra Paliiva u mizhvoiennyi period. / M. Shvahuliak // Ukraina: kulturna spadshchyna, natsionalna svidomist, derzhavnist. Zbirnyk naukovykh prats. - Vypusk 7. - Lviv: Instytut Ukrainoznavstva im. I. Krypiakevycha NAN Ukrainy, 2000. - S. 404-428.

15. Shvahuliak M. Polska represyvna aktsiia u Halychyni 1930 r. i ukrainska suspilnist / M. Shvahuliak. Lviv: Instytut ukrainoznavstva im. I. Krypiakevycha NAN Ukrainy, 1993. - 52 s.

Стаття надійшла до редакиії 20.10.2017 p. 